Check for updates

Cite this: RSC Adv., 2018, 8, 22447

\title{
Efficient access to amides of the carborane carboxylic acid [1-(COOH) $\left.-\mathrm{CB}_{11} \mathrm{H}_{11}\right]^{-} \dagger$
}

\author{
Yunjun Shen, \$ Kai Zheng, \$ Rakesh Dontha, Yani Pan, Jiyong Liu \\ and Simon Duttwyler ${ }^{D}$ *
}

The preparation of the carborane acid chloride $\left[1-(\mathrm{COCl})-\mathrm{CB}_{11} \mathrm{H}_{11}\right]^{-}$from the carboxylic acid [1- $(\mathrm{COOH})-$ $\left.\mathrm{CB}_{11} \mathrm{H}_{11}\right]^{-}$is reported. This acid chloride exhibits remarkable inertness towards moisture and can be stored under ambient conditions for several months. Reaction with amines affords secondary and tertiary carborane amides $\left[1-\left(C O N R^{1} R^{2}\right)-C_{11} H_{11}\right]^{-}$in moderate to high yields under mild conditions. Two of the amide products were characterized by $\mathrm{X}$-ray crystallography in addition to spectroscopic analysis. Preliminary studies show that the amides can be reduced to the corresponding amines and that the acid chloride has the potential to serve as a starting material for carborane ester formation.

Received 10th April 2018

Accepted 11th June 2018

DOI: $10.1039 / \mathrm{c} 8 \mathrm{ra03067g}$

rsc.li/rsc-advances

dicarbo-closo-dodecaborane-1-carbonyl chloride by distillation

\section{Introduction}

Owing to their unique steric and electronic properties, boronbased clusters have been the focus of a growing body of studies that are concerned with their fundamental properties, new methods of their preparation and their applications. Carboranes based on the scaffolds $\left[\mathrm{CB}_{11} \mathrm{H}_{12}\right]^{-}$and $\mathrm{C}_{2} \mathrm{~B}_{10} \mathrm{H}_{12}$ are icosahedral clusters in which one or two $\mathrm{B}-\mathrm{H}$ vertices are replaced by $\mathrm{C}-\mathrm{H}$ (Fig. 1a). Their three-dimensional delocalization of electron density is frequently called $\sigma$ aromaticity, in reference to the $\pi$ aromaticity of organic arenes; it leads to exceptional chemical and thermal stability. ${ }^{1,2} \mathrm{~A}$ large number of applications of carboranes have emerged over the past decade; their utility has become evident in ligand design, ${ }^{3}$ supramolecular $^{4}$ and medicinal ${ }^{5}$ chemistry, as well as fluorescence/ phosphorescence ${ }^{6}$ and materials science. ${ }^{7}$ Weakly coordinating halogenated derivatives of $\mathbf{1}$ are the anions of choice as counterions for cationic reactive intermediates and of highly active catalysts. ${ }^{8}$ Provided the practical versatility of such boron cage compounds, expedient methods that provide access to tailormade derivatives are highly desirable. In many cases, the focus lies on the construction of inorganic-organic hybrid molecules, i.e., coupling of a cluster with an organic molecule.

Early reports on the formation of neutral dicarba-closododecaborane carboxylic acid derivatives stem from Kahl and coworkers. ${ }^{9}$ Starting from carboxylic acids, acid chlorides were prepared using phosphorous pentachloride; the isolation of 1,2-

Department of Chemistry, Zhejiang University, Zheda Road 38, 310027 Hangzhou, P.R. China.E-mail:duttwyler@zju.edu.cn

$\dagger$ Electronic supplementary information (ESI) available: Procedures and spectroscopic data. CCDC 1829932 and 1829933 for $2 \mathbf{e}$ and $2 \mathbf{m}$. For ESI and crystallographic data in CIF or other electronic format see DOI: $10.1039 / \mathrm{c} 8 \mathrm{ra03067g}$

$\ddagger$ These authors contributed equally. was reported in $1999 .^{9 b}$ Subsequent transformations involved the synthesis of carborane carboxylic acid esters. Kaszyński and coworkers have synthesized a large number of monocarba-closododecaborate-based materials based on $\mathrm{C} 1$ vertex ester functionalization. ${ }^{10}$ Their protocols used oxalyl chloride/ dimethylformamide to convert the C1-carboxylic acids to acid chloride intermediates that were not isolated but directly treated with nucleophiles (Fig. 1b).

With respect to medicinal chemistry in particular, carboranes have been used in boron neutron capture therapy, and they have also been demonstrated to be potent pharmacophores, acting as agonists or inhibitors of enzymes. ${ }^{11}$ The amide group is one of the most important functional groups in organic chemistry and biochemistry, and amide moieties are present in peptides, synthetic polymers, many natural products and marketed drugs. ${ }^{12}$ It is in this context that the Scholz group has recently reported on the synthesis of dicarbaborane amides (Fig. 1c)..$^{13}$ Their protocol relied on the use of the reagent (1-cyano-2-ethoxy-2oxoethylideneaminooxy)-(dimethylamino)morpholinocarbenium hexafluorophosphate (COMU), which allowed the coupling of carborane carboxylic acids with amines. Our group's interest in the functionalization of anionic carboranes led us to probe amide moieties as directing groups for $\mathrm{B}-\mathrm{H}$ activation mediated by transition metals. We found that the carborane carboxylic acid [1$\left.(\mathrm{COOH})-\mathrm{CB}_{11} \mathrm{H}_{11}\right]^{-}$can be transformed to pyrrolidine and tosyl amides after activation by a combination of oxalyl chloride and dimethyl formamide (Fig. 1d). ${ }^{14}$ In the current study we show that the corresponding acid chloride is an intermediate that can be isolated in high yield and stored for a prolonged time under ambient conditions. It undergoes substitution with a variety of amines to give secondary and tertiary amides in moderate to high yields (Fig. 1e). X-ray crystal structures and additional transformations are presented as well. 
a)
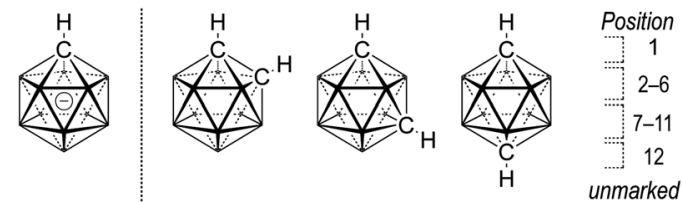

$\left[\mathrm{CB}_{11} \mathrm{H}_{12}\right]^{-}$

$o-\mathrm{C}_{2} \mathrm{~B}_{10} \mathrm{H}_{12} \quad m-\mathrm{C}_{2} \mathrm{~B}_{10} \mathrm{H}_{12} \quad p-\mathrm{C}_{2} \mathrm{~B}_{10} \mathrm{H}_{12}$

unmarked

vertex $=B-H$

b) Kaszyński group
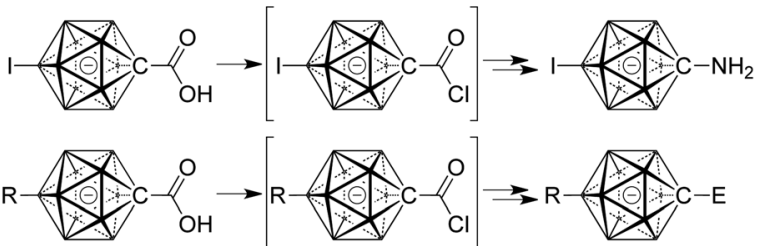

$\mathrm{R}=\mathrm{C}_{6} \mathrm{H}_{13} \quad \begin{array}{ll}\text { acid chloride formation } \\ \text { using }(\mathrm{COCl})_{2} / \mathrm{DMF}\end{array} \quad \begin{aligned} & \mathrm{E}= \\ & \mathrm{C}\end{aligned}$

c) Scholz group

$\left\{C_{2} B_{10}\right\}$-based carborane amides

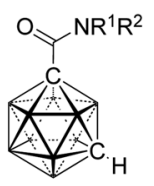

(1)

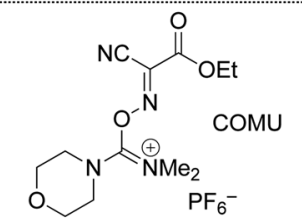

d) Our group

$\left\{\mathrm{CB}_{11}\right\}$-based
carborane amides
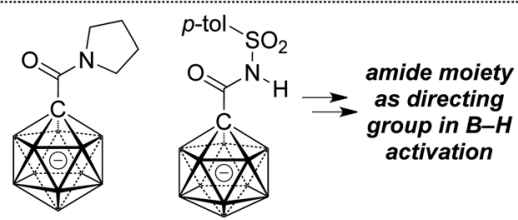

e) This work:

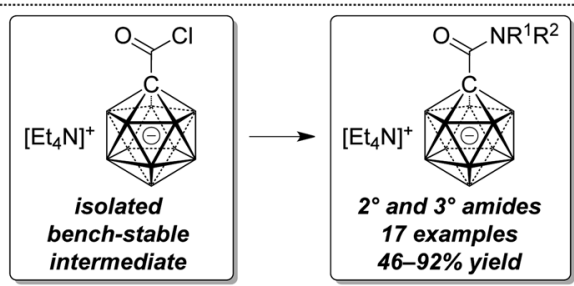

Fig. 1 General structure of icosahedral carboranes (a), reported carborane esters and carboxamides $(b-d)$ and outline of the present study (e).

\section{Results and discussion}

At the outset of our study, we decided to investigate the activation of $\left[1-(\mathrm{COOH})-\mathrm{CB}_{11} \mathrm{H}_{11}\right]^{-}$more thoroughly. Treatment of the acid with 1 equivalent of oxalyl chloride and catalytic amounts of dimethyl formamide in dichloromethane caused clean formation of the acid chloride 1 within $30 \mathrm{~min}$ at $25^{\circ} \mathrm{C}$, as indicated by ${ }^{11} \mathrm{~B}$ NMR spectroscopy and ESI-mass spectrometry (Scheme 1). This species was subsequently successfully isolated by either a classical work-up including removal of volatiles or by simple precipitation upon addition of hexane to the reaction mixture (see the ESI $\dagger$ for details). Both procedures furnished 1 in $87 \%$ yield. Acid chloride 1 exhibits high inertness towards moisture; $\left[\mathrm{Et}_{4} \mathrm{~N}\right][\mathbf{1}]$, stored as a powder in a closed vial under air, remained unchanged over several months. The hydrolysis of $\left[\mathrm{Et}_{4} \mathrm{~N}\right][1]$ in a mixture of acetonitrile/water $(5: 1 \mathrm{v} / \mathrm{v})$ was studied by NMR spectroscopy, and the details of the monitoring are provided in the ESI file (Fig. S1 and $\mathrm{S} 2 \dagger)$. A comparison of the ${ }^{11} \mathrm{~B}\left\{{ }^{1} \mathrm{H}\right\}$ NMR spectra of [1-(COOH)$\left.\mathrm{CB}_{11} \mathrm{H}_{11}\right]^{-}$and 1 showed that these two species can be

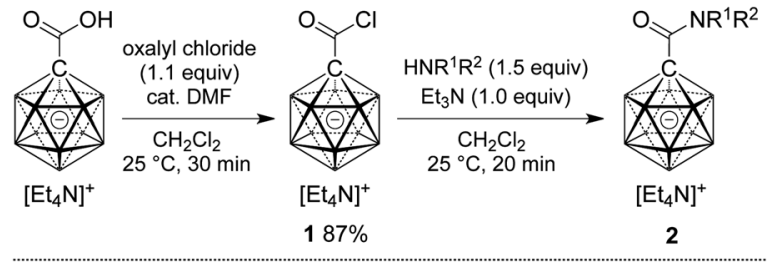

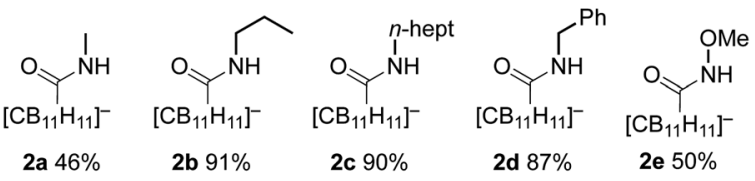<smiles>CC(C)NC(=O)C(F)(F)C(F)(F)C(=O)NC1CCCCC1</smiles>

2f $89 \%$<smiles>O=C(O)N1CCCCC1</smiles>

$\left[\mathrm{CB}_{11} \mathrm{H}_{11}\right]^{-}$

2j $84 \%$

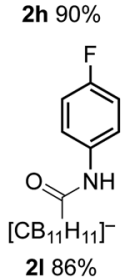

2i $90 \%$<smiles>O=C(Nc1ccc(I)cc1)C(F)(F)C(F)(F)F</smiles>

Scheme 1 Preparation of carboxylic acid chloride 1 and subsequent synthesis of carborane amides 2 . Yields are isolated yields with respect to 1.

distinguished clearly based on the chemical shifts of their B12 and B2-6/7-11 positions (Fig. 2a and b).

We next probed the reactivity of $\mathbf{1}$ towards amines with the aim to prepare a series of carborane amides. Reaction with amines took place at a much higher rate than with water. Addition of 1.5 equivalents of amine cleanly afforded the corresponding amide in dichloromethane within $20 \mathrm{~min}$ at $25^{\circ} \mathrm{C}$; one equivalent of triethylamine was used to neutralize the $\mathrm{HCl}$ byproduct (Scheme 1). Primary unbranched amines afforded products $2 \mathrm{a}-\mathbf{e}$ in yields of $46-91 \%$. Sterically more congested amines afforded the isopropyl, cyclohexyl and tert-butyl derivatives $\mathbf{2 f}-\mathbf{h}$, while pyrrolidine and piperidine gave tertiary amides $2 \mathbf{i}$ and $2 \mathbf{j}$. Anilines proved to be viable sub-strates as well, as demonstrated by the formation of $2 \mathbf{k}-\mathbf{m}$. Compounds 2f-m were obtained in high yields of $84-92 \%$. Isolation of

a)

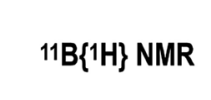

b)

\section{c)}

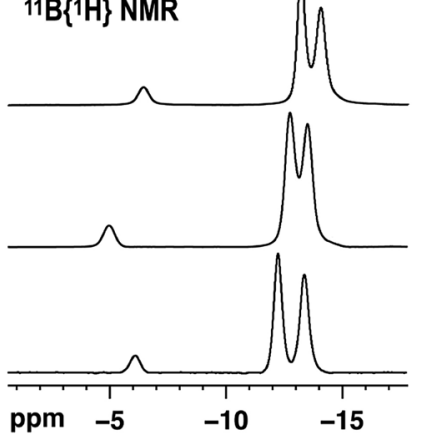

Fig. $2{ }^{11} \mathrm{~B}\left\{{ }^{1} \mathrm{H}\right\}$ NMR spectra of $\left[\mathrm{Et}_{4} \mathrm{~N}\right]\left[1-(\mathrm{COOH})-\mathrm{CB}_{11} \mathrm{H}_{11}\right](\mathrm{a}),\left[\mathrm{Et}_{4} \mathrm{~N}\right][1]$ (b) and $\left[\mathrm{Et}_{4} \mathrm{~N}\right][2 \mathrm{a}]$ (c) (acetone- $d_{6}, 22^{\circ} \mathrm{C}, 160 \mathrm{MHz}$ for ${ }^{11} \mathrm{~B}$ ). 


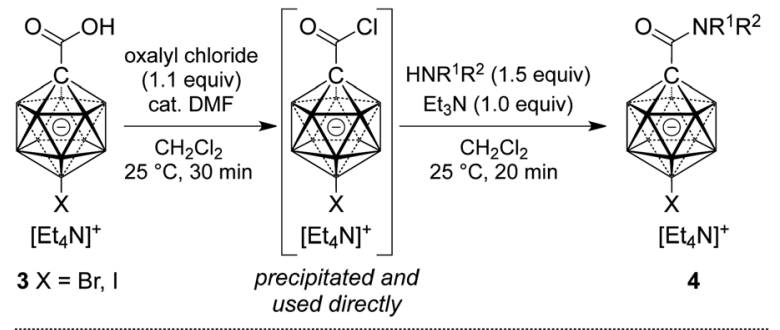

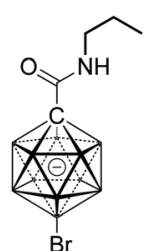

4a $81 \%$

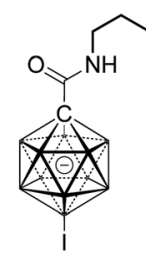

4b $88 \%$

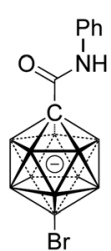

4c $86 \%$

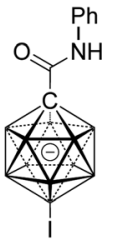

4d $90 \%$
Scheme 2 Synthesis of carborane amides 4 starting from halogenated carborane precursors. Yields are isolated yields with respect to 3 .

amides 2 involved either simple precipitation or purification by silica gel column chromatography. In their ${ }^{11} \mathrm{~B}$ NMR spectra, all products exhibited a characteristic $\mathrm{B} 12$ resonance at -6 to $-7 \mathrm{ppm}$; as a representative example, the ${ }^{11} \mathrm{~B}\left\{{ }^{1} \mathrm{H}\right\}$ NMR spectrum of $\mathbf{2 a}$ is depicted in Fig. 2c.

Cage halogenation affects the properties of boron clusters (e.g., polarity, coordinating ability, solubility) and offers the possibility of further functionalization by transition metalcatalyzed cross coupling. ${ }^{2 a, 2 b, 15}$ Amide formation was probed starting from brominated and iodinated carborane carboxylic acids 3 (Scheme 2). Applying reaction conditions identical to the ones for the synthesis of $\mathbf{2}$, amides $\mathbf{4 a - d}$ were obtained in yields of $81-91 \%$. In these cases, the acid chloride was precipitated from the initial reaction mixture, collected by filtration and used directly in the amide formation step.

X-ray crystallography revealed the solid-state structures of $2 \mathbf{e}$ and $2 \mathbf{m}$. Single crystals of the composition $[\mathrm{Na}]\left[\mathrm{Et}_{4} \mathrm{~N}\right][2 \mathrm{e}]_{2}$ were obtained from an acetonitrile solution in the presence of one equivalent of $\mathrm{Na}^{+}$by slow evaporation (see the ESI $\dagger$ for details). The unit cell contains two $\left\{[\mathrm{Na}]_{2}\left[\mathrm{Et}_{4} \mathrm{~N}\right]_{2}[2 \mathbf{2 e}]_{4}\right\}_{2}$ dimers, both of which feature a center of inversion and coordination of the $\mathrm{Na}^{+}$ centers by oxygen and nitrogen astoms (Fig. 3 and S1†). The

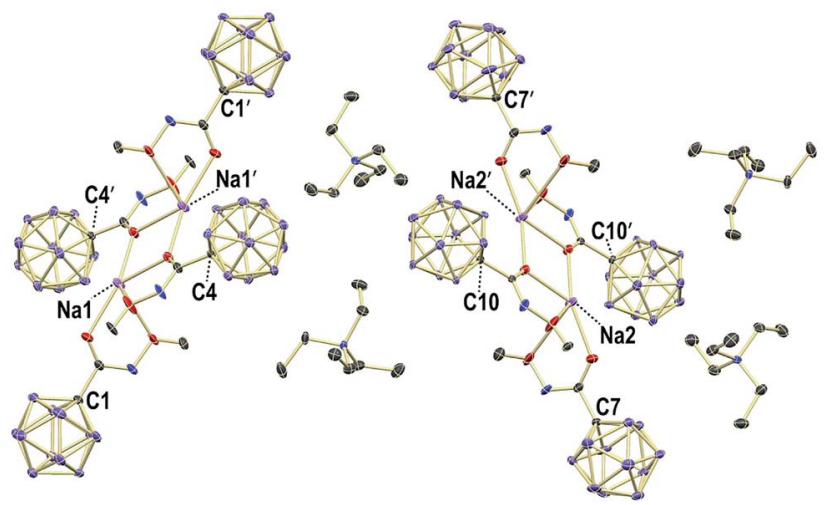

Fig. 3 Packing of $2 \mathrm{e}$ in crystals of the composition $\mathrm{Na}\left[\mathrm{Et}_{4} \mathrm{~N}\right][2 \mathrm{e}]_{2} ; \mathrm{H}$ atoms omitted for clarity; 30\% displacement ellipsoids.

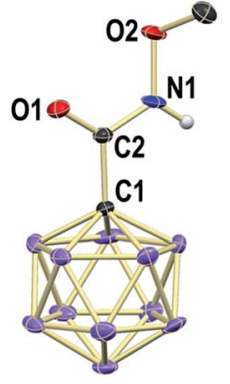

Distances $[\AA \AA]$ and angles $\left[{ }^{\circ}\right]$

C1-C2 1.525(8)

C2-01 1.214(8)

C2-N1 1.339(9)

$\mathrm{N} 1-021.403(7)$

$\Sigma(\mathrm{C} 2) 360.0(6)$

O2-N1-C2-C1 177.1(5)

a)

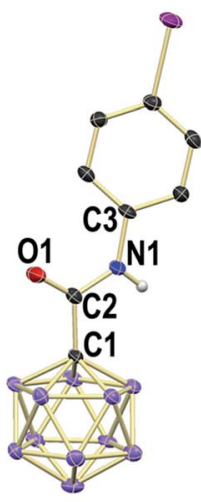

Distances $[\AA]$ and angles $\left[^{\circ}\right]$

C1-C2 1.506(8)

C2-01 1.223(8)

C2-N1 1.359(8)

$\mathrm{N} 1-\mathrm{C} 31.427(7)$

$\Sigma(\mathrm{C} 2) 360.0(6)$

C3-N1-C2-C1 178.7(6)

b)
Fig. 4 X-ray crystal structures of $2 \mathrm{e}(\mathrm{a})$ and $2 \mathrm{~m}$ (b). Cations and $\mathrm{H}$ atoms except for $\mathrm{N}-\mathrm{H}$ omitted for clarity; $30 \%$ displacement ellipsoids.

$\left[\mathrm{Et}_{4} \mathrm{~N}\right]^{+}$cations are well-separated from the anions. The different carboxamides exhibit similar geometries, and the structural parameters of one of them will be summarized (Fig. 4a). Generally, there is a pronounced resemblance to typical organic amides. Observed distances $(\AA)$ for $2 \mathrm{e}$ are C1-C2 1.525(8), C2$\mathrm{O} 1$ 1.214(8) and C2-N1 1.339(9). The sum of angles around C2 is $360.0(6)^{\circ}$, and the torsion angle $\mathrm{O} 2-\mathrm{N} 1-\mathrm{C} 2-\mathrm{C} 1$ of $177.1(5)^{\circ}$ indicates coplanarity of the entire amide moiety. Solvent layering of an acetone solution of $2 \mathrm{~m}$ with hexane gave single crystals of the composition $\left[\mathrm{Et}_{4} \mathrm{~N}\right][2 \mathrm{~m}]$ (Fig. $4 \mathrm{~b}$ and $\mathrm{S} 2 \dagger$ ). The distances (A) and angles are similar to those of $2 \mathbf{e}$, namely, C1-C2 1.506(8), C2-O1 1.223(8), C2-N1 1.359(8), sum of angles around C2 360.0(6) and torsion angle C3-N1-C2-C1 178.7(6) .

Finally, the potential of $\mathbf{1}$ as a precursor of carborane esters and the reduction of two selected amides 2 were investigated. As anticipated from the slow reaction of $\mathbf{1}$ with water, ester formation required more forcing conditions than amide formation. Heating a solution of 1 in methanol at $50{ }^{\circ} \mathrm{C}$ for $5 \mathrm{~h}$ gave methyl ester $\mathbf{5}$ in $91 \%$ yield (Scheme 3a). Treatment of $2 \mathbf{i}$ and $\mathbf{2} \mathbf{j}$ with an excess of lithium aluminum hydride caused

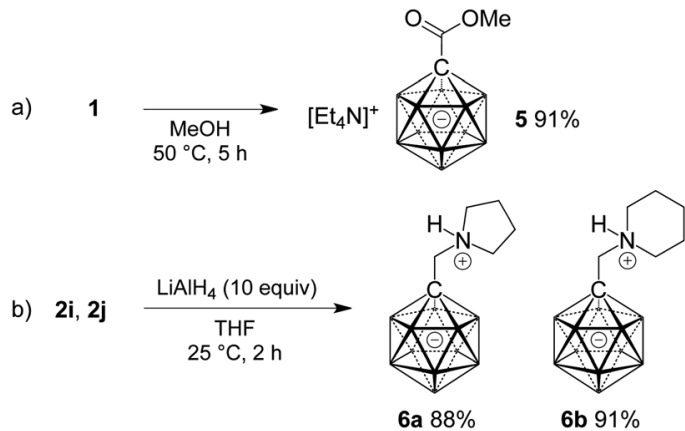

Scheme 3 Ester formation starting from 1 (a) and reduction of amides $2 \mathrm{i}$ and $2 \mathrm{j}(\mathrm{b})$. 
clean reduction to the corresponding amines (Scheme $3 \mathrm{~b}$ ). Isolation under acidic conditions afforded products $\mathbf{6 a}$ and $\mathbf{6 b}$ in as N-protonated zwitterions in yields of $88 \%$ and $91 \%$, respectively.

\section{Conclusions}

In conclusion, the results of this study demonstrate that the carborane acid chloride $\mathbf{1}$ can be conveniently prepared and stored in the form of $\left[\mathrm{Et}_{4} \mathrm{~N}\right][\mathbf{1}]$ under ambient conditions without noticeable decomposition. In combination with amines it affords secondary and tertiary carborane amides $\mathbf{2}$ under mild conditions and generally in high yields. Additional transformations such as ester formation and reduction of products 2 to amines underscore the potential of $\mathbf{1}$ as a versatile starting material towards C1-substituted derivatives of the monocarbacloso-dodedaborate anion. We are currently exploring transformations of $\mathbf{1}$ with other nucleophiles.

\section{Conflicts of interest}

There are no conflicts to declare.

\section{Acknowledgements}

This work was supported by the Natural Science Foundation of China (grant 21472166), the Chinese "1000 Young Talents Plan", and the National Basic Research Program of China (973 Project, grant 2015CB856500).

\section{Notes and references}

1 (a) R. N. Grimes, Carboranes, Elsevier, Amsterdam, 3rd edn, 2016; (b) N. S. Hosmane, Boron Science: New Technologies and Applications, Taylor \& Francis/CRC, Boca Raton, 2011.

2 (a) C. Douvris and J. Michl, Chem. Rev., 2013, 113, PR179PR233; (b) C. Knapp, Weakly Coordinating Anions: Halogenated Borates and Dodecaborates in Comprehensive Inorganic Chemistry II, Elsevier, Amsterdam, 2013, vol. 1, pp. 651-679; (c) R. N. Grimes, Dalton Trans., 2015, 44, 5939-5956; (d) J. Poater, M. Solà and F. Teixidor, Chem.Eur. J., 2016, 22, 7437-7443; (e) P. Melichar, D. Hnyk and J. Fanfrlík, Phys. Chem. Chem. Phys., 2018, 20, 4666-4675; (f) J. C. Axtell, L. M. A. Saleh, E. A. Qian, A. I. Wixtrom and A. M. Spokoyny, Inorg. Chem., 2018, 57, 2333-2350.

3 (a) M. Finze, J. A. P. Sprenger and B. B. Schaack, Dalton Trans., 2010, 39, 2708-2716; (b) A. M. Spokoyny, C. W. Machan, D. J. Clingerman, M. S. Rosen, M. J. Wiester, R. D. Kennedy, C. L. Stern, A. A. Sarjeant and C. A. Mirkin, Nat. Chem., 2011, 3, 590-596; (c) Z.-J. Yao and G.-X. Jin, Coord. Chem. Rev., 2013, 257, 2522-2535; (d) A. El-Hellani and V. Lavallo, Angew. Chem., Int. Ed., 2014, 53, 4489-4493; (e) M. J. Asay, S. P. Fisher, S. E. Lee, F. S. Tham, D. Borchardt and V. Lavallo, Chem. Commun., 2015, 51, 5359-5362; (f) L. E. Riley, A. P. Y. Chan, J. Taylor, W. Y. Man, D. Ellis, G. M. Rosair, A. J. Welch and I. B. Sivaev, Dalton Trans., 2016, 45, 1127-1137; $(g)$
J. Estrada, C. A. Lugo, S. G. McArthur and V. Lavallo, Chem. Commun., 2016, 52, 1824-1826; (h) A. L. Chan, J. Estrada, C. E. Kefalidis and V. Lavallo, Organometallics, 2016, 35, 3257-3260; ( $i$ ) S. P. Fisher, A. El-Hellani, F. S. Tham and V. Lavallo, Dalton Trans., 2016, 45, 9762-9765; (j) J. Holmes, C. M. Pask, M. A. Fox and C. E. Willans, Chem. Commun., 2016, 52, 6443-6446; (k) Y.-P. Zhou, S. Raoufmoghaddam, T. Szilvási and M. Driess, Angew. Chem., Int. Ed., 2016, 55, 12868-12872; (l) F. Šembera, J. Plutnar, A. Higelin, Z. Janoušek, I. Císařová and J. Michl, Inorg. Chem., 2016, 55, 3797-3806; $(\mathrm{m})$ P. Coburger, J. Schulz, J. Klose, B. Schwarze, M. B. Sárosi and E. HeyHawkins, Inorg. Chem., 2017, 56, 292-304; (n) C. Selg, W. Neumann, P. Lönnecke, E. Hey-Hawkins and K. Zeitler, Chem.-Eur. J., 2017, 23, 7932-7937; (o) J. Estrada and V. Lavallo, Angew. Chem., Int. Ed., 2017, 56, 9906-9909.

4 (a) H. Jude, H. Disteldorf, S. Fischer, T. Wedge, A. M. Hawkridge, A. M. Arif, M. F. Hawthorne, D. C. Muddiman and P. J. Stang, J. Am. Chem. Soc., 2005, 127, 1231-12139; (b) S.-L. Huang, L.-H. Weng and G.-X. Jin, Dalton Trans., 2012, 41, 11657-11662; (c) L. Kobr, K. Zhao, Y. Shen, R. K. Shoemaker, C. T. Rogers and J. Michl, Adv. Mater., 2013, 25, 443-448; (d) R. D. Kennedy, V. Krungleviciute, D. J. Clingerman, J. E. Mondloch, Y. Peng, C. E. Wilmer, A. A. Sarjeant, R. Q. Snurr, J. T. Hupp, T. Yildirim, O. K. Farha and C. A. Mirkin, Chem. Mater., 2013, 25, 3539-3543; (e) Y.-F. Han and G.-X. Jin, Acc. Chem. Res., 2014, 47, 3571-3579; $(f)$ C. E. Housecroft, J. Organomet. Chem., 2015, 798, 218-228; (g) D. J. Clingerman, W. Morris, J. E. Mondloch, R. D. Kennedy, A. A. Sarjieant, C. Stern, J. T. Hupp, O. K. Farha and C. A. Mirkin, Chem. Commun., 2015, 51, 6521-6523; (h) S. Rodríguez-Hermida, M. Y. Tsang, C. Vignatti, K. C. Stylianou, V. Guillerm, J. Pérez-Carvajal, F. Teixidor, C. Viñas, D. Choquesillo-Lazarte, C. VerdugoEscamilla, I. Peral, J. Juanhuix, A. Verdaguer, I. Imaz, D. Maspoch and J. Giner Planas, Angew. Chem., Int. Ed., 2016, 55, 16049-16053; (i) M. Y. Tsang, S. RodríguezHermida, K. C. Stylianou, F. Tan, D. Negi, F. Teixidor, C. Viñas, D. Choquesillo-Lazarte, C. Verdugo-Escamilla, M. Guerrero, J. Sort, J. Juanhuix, D. Maspoch and J. Giner Planas, Cryst. Growth Des., 2017, 17, 846-857.

5 (a) I. B. Sivaev and V. V. Bregadze, Eur. J. Inorg. Chem., 2009, 1433-1450; (b) F. Issa, M. Kassiou and L. M. Rendina, Chem. Rev., 2011, 111, 5701-5722; (c) M. Scholz and E. H-Hawkins, Chem. Rev., 2011, 111, 7035-7062; (d) D. Gabel, Pure Appl. Chem., 2015, 87, 173-179; (e) Z. J. Leśnikowski, J. Med. Chem., 2016, 59, 7738-7758.

6 (a) Y.-J. Cho, S.-Y. Kim, M. Cho, W.-S. Han, H.-J. Son, D. W. Cho and S. O. Kang, Phys. Chem. Chem. Phys., 2016, 18, 9702-9708; (b) B. H. Choi, J. H. Lee, H. Hwang, K. M. Lee and M. H. Park, Organometallics, 2016, 35, 17711777; (c) B. P. Dash, R. Satapathy, E. R. Gaillard, J. A. Maguire and N. S. Hosmane, J. Am. Chem. Soc., 2016, 132, 6578-6587; (d) S. Mukherjee and P. Thilagar, Chem. Commun., 2016, 52, 1070-1093; (e) J. C. Axtell, K. O. Kirlikovali, P. I. Djurovich, D. Jung, V. T. Nguyen, 
B. Munekiyo, A. T. Royappa, A. L. Rheingold and A. M. Spokoyny, J. Am. Chem. Soc., 2016, 138, 15758-15765; (f) R. Núñez, M. Tarrés, A. Ferrer-Ugalde, F. F. de Biani and F. Teixidor, Chem. Rev., 2016, 116, 14307-14378; $(g)$ H. Naito, K. Nishino, Y. Morisaki, K. Tanaka and Y. Chujo, Angew. Chem., Int. Ed., 2017, 56, 254-259; (h) A. FerrerUgalde, J. Cabrera-González, E. J. Juárez-Pérez, F. Teixidor, E. Pérez-Inestrosa, J. M. Montenegro, R. Sillanpää, M. Haukka and R. Núñez, Dalton Trans., 2017, 46, 20912104; ( $i$ ) N. V. Nghia, J. Oh, J. Jung and M. H. Lee, Organometallics, 2017, 36, 2573-2580; (j) N. Shin, S. Yu, J. H. Lee, H. Hwang and K. M. Lee, Organometallics, 2017, 36, 1522-1529; (k) M. Hailmann, N. Wolf, R. Renner, B. Hupp, A. Steffen and M. Finze, Chem.-Eur. J., 2017, 23, 11684-11693.

7 (a) K. Tanaka and Y. Chujo, Macromol. Rapid Commun., 2012, 33, 1235-1255; (b) E. G. Cansu-Ergun and A. Cihaner, Mater. Chem. Phys., 2013, 143, 387-392; (c) J. Pecyna, D. Pociecha and P. Kaszyński, J. Mater. Chem. C, 2014, 2, 1585-1591; (d) T. J. Carter, R. Mohtadi, T. S. Arthur, F. Mizunl, R. Zhang, S. Shirai and J. W. Kampf, Angew. Chem., Int. Ed., 2014, 53, 3173-3177; (e) S. G. McArthur, L. Geng, J. Guo and V. Lavallo, Inorg. Chem. Front., 2015, 2, 1101-1104; $(f)$ J. Pecyna, P. Kaszyński, B. Ringstrand, D. Pociecha, S. Pakhomov, A. G. Douglass and V. G. Young Jr, Inorg. Chem., 2016, 55, 4016-4025; $(g)$ R. Núñez, I. Romero, F. Teixidor and C. Viñas, Chem. Soc. Rev., 2016, 45, 51475173; (h) R. Furue, T. Nishimoto, I. S. Park, J. Lee and T. Yasuda, Angew. Chem., Int. Ed., 2016, 55, 7171-7175; (i) S. G. McArthur, R. Jay, L. Geng, J. Guo and V. Lavallo, Chem. Commun., 2017, 53, 4453-4456; (j) Y. Zhu and N. S. Hosmane, J. Organomet. Chem., 2017, 849-850, 286-292. 8 (a) K.-C. Kim, C. A. Reed, D. W. Elliott, L. J. Mueller, F. Tham, L. Lin and J. B. Lambert, Science, 2002, 297, 825-827; (b) T. Kato and C. A. Reed, Angew. Chem., Int. Ed., 2004, 43, 2908-2911; (c) C. Douvris and O. V. Ozerov, Science, 2008, 31, 1188-1190; (d) O. Allemann, S. Duttwyler, P. Romanato, K. K. Baldridge and J. S. Siegel, Science, 2011, 332, 574-577; (e) C. A. Reed, Acc. Chem. Res., 2010, 43, 121-128; (f) Y. Shoji, N. Tanaka, K. Mikami, M. Uchiyama and T. Fukushima, Nat. Chem., 2014, 6, 498-503; $(g)$ B. Shao, A. L. Bagdasarian, S. Popov and H. M. Nelson, Science, 2017, 355, 1403-1407.
9 (a) S. B. Kahl, Tetrahedron Lett., 1990, 31, 1517-1520; (b) R. A. Kasar, G. M. Knudsen and S. T. Kahl, Inorg. Chem., 1999, 38, 2936-2940.

10 (a) A. Jankowiak, J. Kanazawa, P. Kaszyński, R. Takita and M. Uchiyama, J. Organomet. Chem., 2013, 747, 195-200; (b) J. Pecyna, D. Pociecha and P. Kaszyński, J. Mater. Chem. C, 2014, 2, 1585-1591; (c) J. Pecyna, R. P. Denicola, H. M. Gray, B. Ringstrand and P. Kaszyński, Liq. Cryst., 2014, 41, 1188-1198; (d) A. Jankowiak, A. Sivaramamoorthy, D. Pociecha and P. Kaszyński, RSC Adv., 2014, 4, 53907-53914.

11 For selected recent publications on carboranes in medicinal chemistry, see the following references and also ref. 5e:(a) M. B. Sarosi, W. Neumann, T. P. Lybrand and E. HeyHawkins, J. Chem. Inf. Model., 2017, 57, 2056-2067; (b) R. Kawasaki, Y. Sasaki and K. Akiyoshi, Biochem. Biophys. Res. Commun., 2017, 483, 147-152; (c) K. Ohta, T. Ogawa and Y. Endo, Bioorg. Med. Chem. Lett., 2017, 27, 4030-4033; (d) I. Takeuchi, K. Nomura and K. Makino, Colloids Surf., $B$, 2017, 159, 360-365; (e) A. Kaise, K. Ohta, C. Shirata and Y. Endo, Bioorg. Med. Chem., 2017, 25, 6417-6426; (f) A. Kaise, K. Ohta and Y. Endo, Bioorg. Med. Chem., 2017, 25, 6371-6378; (g) D. C. Tribovane and M. S. Scholz, Chem. Phys. Lipids, 2018, 210, 149-154; (h) S. C. Kohler, S. Vandati, M. S. Scholz and M. Wiese, Eur. J. Med. Chem., 2018, 146, 483-500; (i) G. Calabrese, A. Daou, E. Barbu and J. Tsibouklis, Drug Discovery Today, 2018, 23, 63-75; (j) T. Lutzenburg, I. Neundorf and M. Scholz, Chem. Phys. Lipids, 2018, 213, 62-67.

12 J. Zabicky, Chemistry of the Amides (Patai's Chemistry of Functional Groups), John Wiley \& Sons, New York, 1970.

13 M. Scholz and L. M. Wingen, Inorg. Chem., 2017, 56, 55105513.

14 (a) Y. Shen, Y. Pan, J. Liu, T. Sattasathuchana, K. K. Baldridge and S. Duttwyler, Chem. Commun., 2016, 53, 176-179; (b) Y. Shen, Y. Pan, K. Zhang, X. Liang, B. Spingler and S. Duttwyler, Dalton Trans., 2017, 46, 3135-3140; (c) Y. Shen, J. Liu, T. Sattasathuchana, K. K. Baldridge and S. Duttwyler, Eur. J. Inorg. Chem., 2017, 4420-4424.

15 For cross coupling reactions of carboranes, see the following reference and references cited therein: R. M. Dziedzic, L. M. A. Saleh, J. C. Axtell, J. L. Martin, S. L. Stevens, A. T. Royappa, A. L. Rheingold and A. M. Spokoyny, J. Am. Chem. Soc., 2016, 138, 9081-9084. 